\title{
STAT3 modulates $\beta$-cell cycling in injured mouse pancreas and protects against DNA damage
}

\author{
S De Groef ${ }^{1}$, D Renmans ${ }^{1}$, Y Cai ${ }^{1}$, G Leuckx ${ }^{1}$, S Roels ${ }^{1}$, W Staels ${ }^{1,2,3}$, G Gradwohl ${ }^{4}$, L Baeyens ${ }^{1,5}$, Y Heremans ${ }^{1}$, GA Martens ${ }^{1,6}$, \\ N De Leu ${ }^{1,7,8}$, M Sojoodi ${ }^{1}$, M Van de Casteele ${ }^{1,9}$ and H Heimberg ${ }^{\star, 1,9}$
}

Partial pancreatic duct ligation (PDL) of mouse pancreas induces a doubling of the $\beta$-cell mass mainly through proliferation of preexisting and newly formed $\beta$-cells. The molecular mechanism governing this process is still largely unknown. Given the inflammatory nature of PDL and inflammation-induced signaling via the signal transducer and activator of transcription 3 (STAT3), the activation and the role of STAT3 in PDL-induced $\beta$-cell proliferation were investigated. Duct ligation stimulates the expression of several cytokines that can act as ligands inducing STAT3 signaling and phosphorylation in $\beta$-cells. $\beta$-Cell cycling increased by conditional $\beta$-cell-specific Stat 3 knockout and decreased by STAT3 activation through administration of interleukin-6. In addition, the level of DNA damage in $\beta$-cells of PDL pancreas increased after deletion of Stat3. These data indicate a role for STAT3 in maintaining a steady state in the $\beta$-cell, by modulating its cell cycle and protection from DNA damage.

Cell Death and Disease (2016) 7, e2272; doi:10.1038/cddis.2016.171; published online 23 June 2016

Signal transducers and activators of transcription (STAT) proteins are $\mathrm{SH} 2$ domain-containing cytoplasmic transcription factors expressed by various cell types. On receptor binding, specific cytokines, growth factors and hormones induce tyrosine phosphorylation, dimerization and activation of STAT proteins. ${ }^{1}$ Although discrete phenotypes have been described after ablation of most Stat genes, Stat3 knockout results in early embryonic lethality. ${ }^{2}$ This ubiquitously expressed transcription factor is activated by a large number of ligands, including all members of the interleukin 6 (IL6) cytokine family. Among other factors that activate STAT3 in a cell-dependent manner are the IL10 cytokine family, interferons (IFNs), leptin, prolactin, epidermal growth factor (EGF), vascular endothelial growth factor (VEGF), Hepatocyte growth factor (HGF), platelet-derived growth factor (PDGF) and colony-stimulating factors (CSFs). ${ }^{2,3}$ Tissue-specific conditional knockout of Stat3 identified a role for STAT3 in cell migration, ${ }^{4-6}$ cell proliferation, ${ }^{7}$ (anti/pro)apoptotic signaling, ${ }^{7,8}$ expression of acute-phase response genes, $^{9}$ anti-inflammatory ${ }^{10}$ and neurotrophic signaling. ${ }^{11}$

In Stat $3^{\text {lox/lox }}$ mice that express Cre recombinase under the control of the $P d x 1$ promoter, ${ }^{12,13}$ some studies excluded a role for STAT3 in the development and function of the pancreatic $\beta$-cells, ${ }^{13}$ whereas others observed glucose intolerance and impaired insulin secretion as a result of reduced VEGF-A signaling and abnormal islet vascularization. ${ }^{12,14}$ Stat $3^{\text {lox/lox }}$ mice with insulin promotor-driven Cre recombinase are glucose intolerant. ${ }^{15,16}$ Although these studies suggest a contribution for STAT3 in $\beta$-cell function, ${ }^{16}$ its role in $\beta$-cell proliferation and survival is unknown. Mature $\beta$-cells mainly renew by self-replication ${ }^{17,18}$ and their replication potential is homogenous and delayed by a postmitotic quiescence period under normal physiological conditions and following minor injury. ${ }^{19,20}$ We have previously shown that severe pancreatic injury impacted by partial pancreatic duct ligation (PDL) leads to a doubling in $\beta$-cell mass ${ }^{21}$ that mainly results from proliferation of $\beta$-cells, prone to re-divide without refractory period. ${ }^{22}$ This process occurs distal to the ligation of the main pancreatic duct, suggesting autocrine or paracrine regulation, likely induced by the inflammatory environment of PDL that is characterized by expression of transforming growth factor- $a$, gastrin, IL1a, IL1b, IL6, IL10, IFN- $\gamma$ and tumor necrosis factor. ${ }^{23-25}$ However, this list of factors is likely incomplete and their role in PDL-induced $\beta$-cell proliferation remains to be determined. Growth factors such as those of the IGF and EGF family, lactogens, hepatocyte growth factor (HGF), glucagonlike peptide-1 and parathyroid hormone-related protein stimulate rodent $\beta$-cell proliferation and survival in vitro and in vivo. ${ }^{26-28}$ In addition, cytokines, including members of the IL6 family, IL10 and IL27, regulate $\beta$-cell survival. ${ }^{26-33}$ As some of these factors are able to activate STAT3, a role for STAT3 in $\beta$-cell mass maintenance can be envisioned.

We report activation of STAT3 in $\beta$-cells of PDL pancreas and identified factors that are potential activators of the

\footnotetext{
${ }^{1}$ Diabetes Research Center, Vrije Universiteit Brussel, Laarbeeklaan 103, Brussels 1090, Belgium; ${ }^{2}$ Division of Pediatric Endocrinology, Department of Pediatrics, Ghent University Hospital, Ghent, Belgium; ${ }^{3}$ Department of Pediatrics and Genetics, Ghent University, Ghent, Belgium; ${ }^{4}$ Development and Stem Cells, Institute of Genetics and Molecular and Cellular Biology (IGBMC), Illkirch 67404, France; ${ }^{5}$ Diabetes Center, Eli and Edythe Broad Center for Regenerative Medicine and Stem Cell Research, University of California San Francisco, San Francisco, CA 94143-0669, USA; ${ }^{6}$ Department of Clinical Chemistry and Radio-immunology, Universitair Ziekenhuis Brussel (UZ Brussel), Laarbeeklaan 101, Brussels 1090 Belgium; ; Department of Endocrinology, UZ Brussel, Brussels 1090, Belgium and ${ }^{8}$ ASZ Aalst, Aalst, Belgium ${ }^{*}$ Corresponding author: H Heimberg, Diabetes Research Center, Vrije Universiteit Brussel, Laarbeeklaan 103, Brussels 1090, Belgium. Tel: +32 2 47744777; Fax: +32 2 4774472; E-mail: Harry.Heimberg@ @ub.ac.be

${ }^{9}$ These authors are the senior authors.
}

Abbreviations: Stat3, signal transducer and activator of transcription 3; PDL, partial pancreatic duct ligation; RT-PCR, reverse transcription PCR; R26, Rosa 26 locus; RIP, rat insulin promoter; TAM, tamoxifen; YFP, yellow fluorescent protein

Received 30.11.15; revised 02.5.16; accepted 03.5.16; Edited by A Stephanou 
a

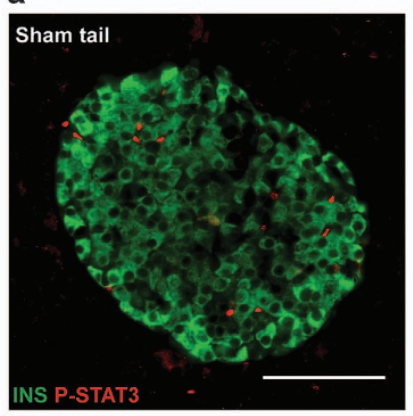

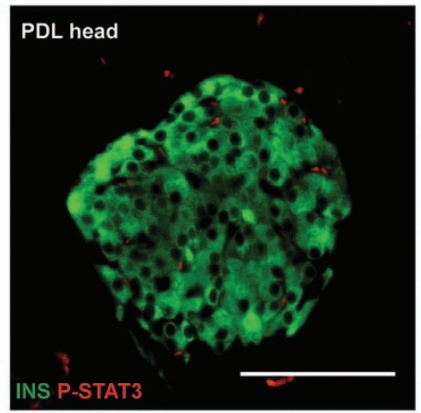

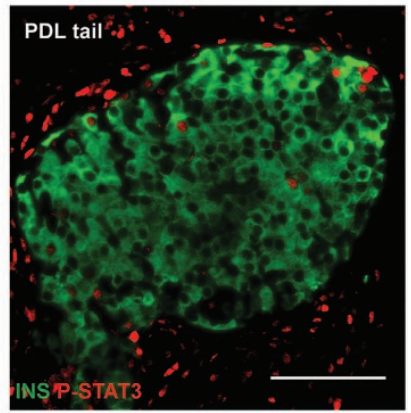

b

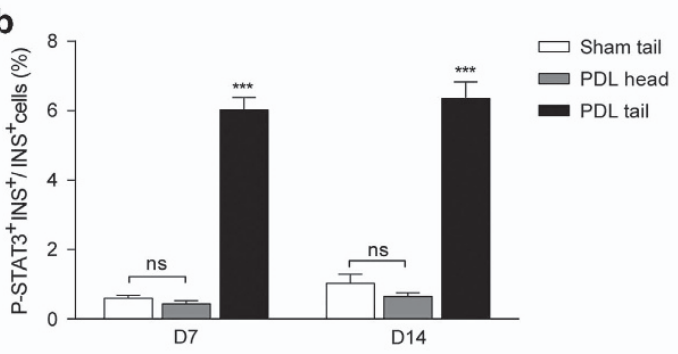

C

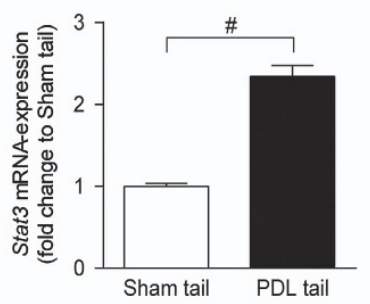

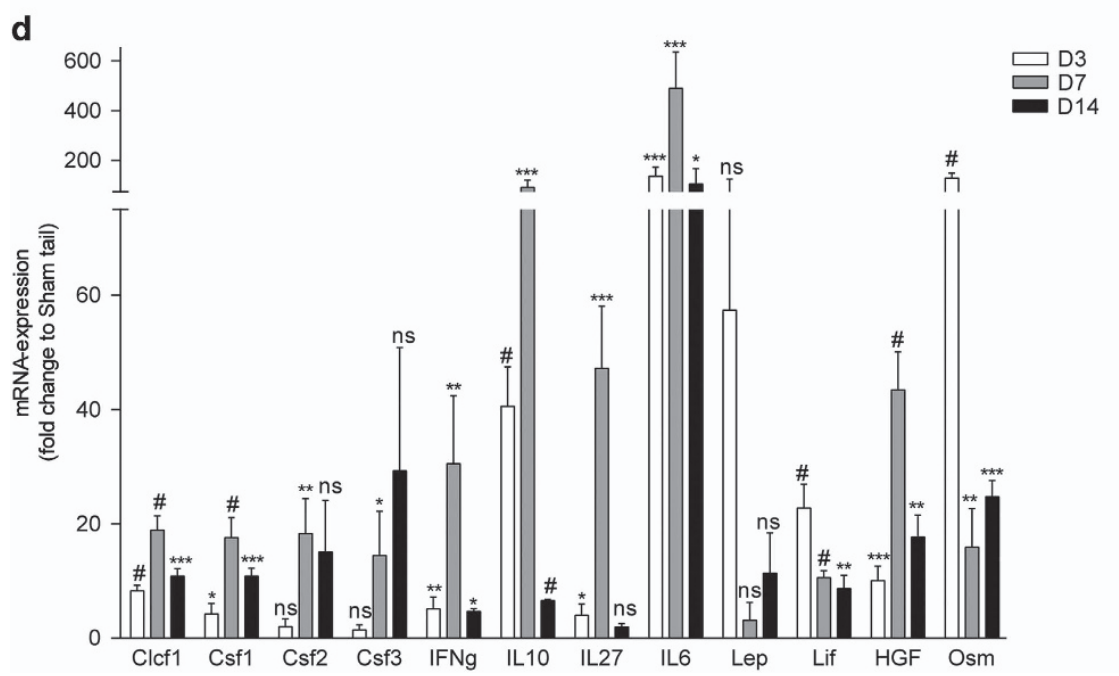

Figure 1 STAT3 expression and activity are stimulated in $\beta$-cells of PDL pancreas. (a) Immunostaining for phospho-STAT3 (Y705) (P-STAT3) and insulin in Sham tail, PDL head and PDL tail. (b) Quantification of data in a: percentage of P-STAT $3^{+}$INS ${ }^{+}$cells at day 7 and 14 (D7 and D14) postsurgery (mean \pm S.E.M., $n=3$, ${ }^{* \star *} P<0.001, n s: P>0.05$, two-way ANOVA). (c) Stat3 mRNA in $\beta$-cells isolated at D7 from the tail of Sham- and PDL pancreas of MIP-RFP mice. Data are expressed as fold change versus Sham ( $=1$ ) $\left(n=3,{ }^{\#} P<0.0001\right.$, Sham tail versus PDL tail by unpaired two-tailed $t$-test). (d) STAT3-activating factors whose expression increased 10-fold or more in PDL pancreas. Data represent the fold change in expression of each factor in PDL tail as compared with its expression in Sham tail (1) (D3: $n=4, D 7: n=4, D 14: n=3,{ }^{*} P<0.05,{ }^{* *} P<0.005$, ${ }^{* * *} P<0.001,{ }^{\#} P<0.0001$, ns: $P>0.05$, Sham tail versus PDL tail by unpaired two-tailed $t$-test)

JAK2/STAT3 pathway. In PDL pancreas, STAT3 modulates the $\beta$-cell cycle and protects $\beta$-cells from DNA damage.

\section{Results}

PDL-induced injury activates STAT3 in $\beta$-cells. Eight weeks old BALB/cJRj mice underwent PDL or sham surgery and the expression of Stat3 transcript and protein was evaluated at day (D) 7 and 14 post surgery. STAT3 protein was detected in islets in the tail of ligated pancreas (PDL tail), in the tail of sham pancreas (Sham tail) and in the non-ligated head of PDL pancreas (PDL head) (Supplementary Figure S1a). To study STAT3 activation, the expression of phosphorylated STAT3 ${ }^{\text {Y705 }}$ (from hereon called P-STAT3) was examined using a P-STAT3 ${ }^{\text {Y705 }}$-specific antibody. Significantly more P-STAT3 ${ }^{+}$nuclei were identified among INS ${ }^{+}$ $\beta$-cells of PDL tail at D7 and D14 following surgery, as compared with PDL head or Sham tail $(n=3 ; P \leq 0.005)$ (Figures 1a and b). P-STAT3 ${ }^{+}$nuclei were also observed among glucagon (GCG) ${ }^{+} a$-cells (Supplementary Figure S1b and Cai et al. ${ }^{34}$ ) and among keratin (KRT) $19^{+}$duct cells 
(Supplementary Figure S1c) of PDL tail. Although the abundance of Stat3 mRNA in total PDL tail pancreas was similar to Sham tail and PDL head pancreas(data not shown), $\beta$-cells isolated from MIP-mRFP D7 PDL tail pancreas contained twice as much Stat3 transcript compared with $\beta$-cells isolated from Sham tail pancreas (Figure 1c), suggesting $\beta$-cellspecific increase of Stat3 gene expression.

PDL stimulates the expression of STAT3-activating cytokines and growth factors. Next, the nature of PDLinduced STAT3 activators was investigated. PDL is characterized by acinar cell loss and formation of neoplastic ducts, accompanied by a local influx of inflammatory CD $45^{+}$ cells. ${ }^{21}$ The cytokine profile of PDL pancreas has been partially characterized. ${ }^{24,25}$ A literature search revealed 35 potential activators of STAT3 (Table 1) and their mRNA abundance was investigated under our experimental conditions. The expression of 12 of these factors increased more than 10-fold in PDL versus sham tail (Figure 1d). Among these, IL6 was most strongly induced (488-fold increase), whereas transcript levels of Clcf1, Csf1, Csf2, Csf3, Ifng, IL10, IL27, Lep, Lif, Hgf and Osm also increased (Figure 1d). Cytokines with moderately increased transcript level (between 1- and 10-fold) included Igf1, IL2, IL7, IL11, IL 15, IL 19, Cntf and Pdgfb (Supplementary Figure S2a). The expression of three factors (Ctf1, Egf and Vegfa) remained either unchanged or decreased in PDL versus Sham tail (Supplementary Figure S2b). Finally, a group of nine cytokines known to activate STAT3, including IL9, Ctf2, Ifna4, Ifna5, IL20, IL21, IL22, IL24 and IL31, remained undetected. PDL thus creates an inflammatory microenvironment, characterized by increased expression of STAT3-activating cytokines among which IL6 is most prominent.

Cycling $\boldsymbol{\beta}$-cells rarely activate STAT3. STAT3 supports cell cycling of B-lymphocytes and several cancer cell types. ${ }^{35-37}$ Therefore, we examined expression of P-STAT3 in actively cycling $\mathrm{Ki}^{+} 7^{+} \mathrm{INS}^{+} \beta$-cells. At D7 and D14, respectively, 2.8and 2.5 -fold more $\mathrm{Ki}^{+} 7^{+} \mathrm{INS}^{+}$cells were observed in PDL as compared with Sham tail $(n=3-6, P<0.005)$ (Figure 2a). These data confirm our earlier reports ${ }^{21,34,38}$ and indicate that, in PDL tail, both $\beta$-cell cycle and the number of $\beta$-cells with activated STAT3 are increased. In line with our previous observations, $\mathrm{Ki}^{+} 7^{+} \beta$-cells and P-STAT3 ${ }^{+} \beta$-cells were more abundant in small islets of $<20 \beta$-cells as compared with larger islets at D7 and D14 post PDL (Figure 2b,c). However, no P-STAT3 ${ }^{+} \mathrm{Ki} 7^{+} \beta$-cells were observed in PDL tail at D7 or D14 (Figure 2d and Table 2). The close to zero probability to find a P-STAT3 ${ }^{+} \mathrm{Ki}_{67}{ }^{+} \beta$-cell in PDL tail, as calculated by the Wilson score confidence interval $(95 \%)(P<0.001$, Table 2$)$, indicates that the population of cycling $\beta$-cells does not overlap with the population of $\beta$-cells with activated STAT3. This phenomenon appears specific for $\beta$-cells, as P-STAT3 ${ }^{+}$ $\mathrm{Ki} 7^{+}$duct- and $\alpha$-cells were observed under the same experimental conditions (Supplementary Figure S2c).

Conditional Stat3 knockout increases $\beta$-cell cycling in PDL pancreas. The functional role of STAT3 in $\beta$-cells of PDL pancreas was investigated in $R I P^{C r e E R T} ; R 26^{\text {YFP }} ;$ Stat3 ${ }^{\text {lox/lox }}$ mice (Figure $3 a$ ) that received tamoxifen (TAM) at 5 weeks
Table 1 Potential STAT3-activating cytokines and growth factors

\begin{tabular}{|c|c|}
\hline Gene & Assay ID \\
\hline $\begin{array}{l}\text { IL-6 family } \\
\text { IL-6 } \\
\text { IL-11 } \\
\text { IL-31 } \\
\text { Osm } \\
\text { LIF } \\
\text { CNTF } \\
\text { Ctf1 } \\
\text { Ctf2 } \\
\text { Clcf1 }\end{array}$ & $\begin{array}{l}\text { Mm.PT.53.10005566 } \\
\text { Mm.PT.53.9688576 } \\
\text { Mm.PT.53.30234305 } \\
\text { Mm.PT.53.10391002 } \\
\text { Mm.PT.5328778894 } \\
\text { Mm.PT.5332700675.g } \\
\text { Mm.PT.53.5674019 } \\
\text { Mm.PT.53.10088537 } \\
\text { Mm.PT.53.10279842 }\end{array}$ \\
\hline $\begin{array}{l}\text { IL-10 family } \\
\text { IL-10 } \\
\text { IL-19 } \\
\text { IL-20 } \\
\text { IL-22 } \\
\text { IL-24 }\end{array}$ & $\begin{array}{l}\text { Mm.PT.53.13531087 } \\
\text { Mm.PT.53.10424485 } \\
\text { Mm.PT.53.30487665 } \\
\text { Mm.PT.53.33202172 } \\
\text { Mm.PT.53.11689874 }\end{array}$ \\
\hline $\begin{array}{l}\text { Interferons } \\
\text { IFNa4 } \\
\text { IFNa5 } \\
\text { IFN } \beta 1 \\
\text { IFNy }\end{array}$ & $\begin{array}{l}\text { Mm.PT.53.31028456.g } \\
\text { Mm.PT.53.32377263.g } \\
\text { Mm.PT.53.29124254.g } \\
\text { Mm.PT.53.13380517 }\end{array}$ \\
\hline $\begin{array}{l}\text { Common } \gamma \text {-chain family } \\
\text { IL-2 } \\
\text { IL-7 } \\
\text { IL-9 } \\
\text { IL-15 } \\
\text { IL-21 }\end{array}$ & $\begin{array}{l}\text { Mm.PT.53.11478202 } \\
\text { Mm.PT.53.10325839 } \\
\text { Mm.PT.53.17016816 } \\
\text { Mm.PT.53.33007558.g } \\
\text { Mm.PT.53.7853071 }\end{array}$ \\
\hline $\begin{array}{l}\text { Growth Factors and hormones } \\
\text { Csf-1 } \\
\text { Csf-2 } \\
\text { Csf-3 } \\
\text { EGF } \\
\text { HGF } \\
\text { IGF-1 } \\
\text { VEGFa } \\
\text { PDGF } 3 \\
\text { Lep }\end{array}$ & $\begin{array}{l}\text { Mm.PT.53a.32521769 } \\
\text { Mm.PT.53a.30204640 } \\
\text { Mm.PT.53.14133107.g } \\
\text { Mm.PT.53.6246680 } \\
\text { Mm.PT.53.9088506 } \\
\text { Mm.PT.53.32726889 } \\
\text { Mm.PT.53.31754187.g } \\
\text { Mm.PT.53a.32585335 } \\
\text { Mm.PT.53.13515402 }\end{array}$ \\
\hline $\begin{array}{l}\text { IL-12 family } \\
\text { IL-27 }\end{array}$ & Mm.PT.53.12354802 \\
\hline $\begin{array}{l}\text { Inflammatory cytokines } \\
\text { IL-1 } \\
\text { Tumor Necrosis Factor } a(T N F a)\end{array}$ & $\begin{array}{l}\text { Mm.PT.53a.16901608 } \\
\text { Mm.PT.56a.12575861 }\end{array}$ \\
\hline
\end{tabular}

of age, followed by a 14 days washout period. PDL was performed at 8 weeks of age and analysis was carried out 2 weeks later. As the efficiency of recombination in $\beta$-cells was high $\left(89.9 \pm 1.11 \%\right.$ of INS $^{+}$cells were $\mathrm{YFP}^{+}$) (Figure $3 \mathrm{~b}$ ), $R I P^{C r e E R T} ; R 26^{Y F P} ; S_{\text {Stat3 }}{ }^{\text {lox/lox }}$ mice that received TAM are hereafter referred to as Stat ${ }^{-/}$. Accordingly, an $85.8 \%$ reduction in $\mathrm{STAT3}^{+} \beta$-cells was observed in PDL tail of Stat $^{-1}$ mice versus wild-type (WT) littermates $(n=4)$ (Figures $3 \mathrm{c}$ and $\mathrm{d}$ ). Bodyweight, glycemia and glucose tolerance (as determined by IPGTT) were similar in Stat3 ${ }^{-1}$ and WT, both before and after PDL (Supplementary Figures $\mathrm{S} 3 \mathrm{a}-\mathrm{C})$. The islet architecture in $S t a t 3^{-/}$mice appeared normal (Figure 3e). In addition, the percentage of $\mathrm{Ki}^{+} 7^{+}$ $\beta$-cells was similar in PDL heads of WT and Stat $^{-1}$ mice (Figure 3f). The percentage of $\mathrm{Ki}^{+} 7^{+} \beta$-cells in PDL tail as compared with PDL head was 4.5-fold higher In WT mice, 

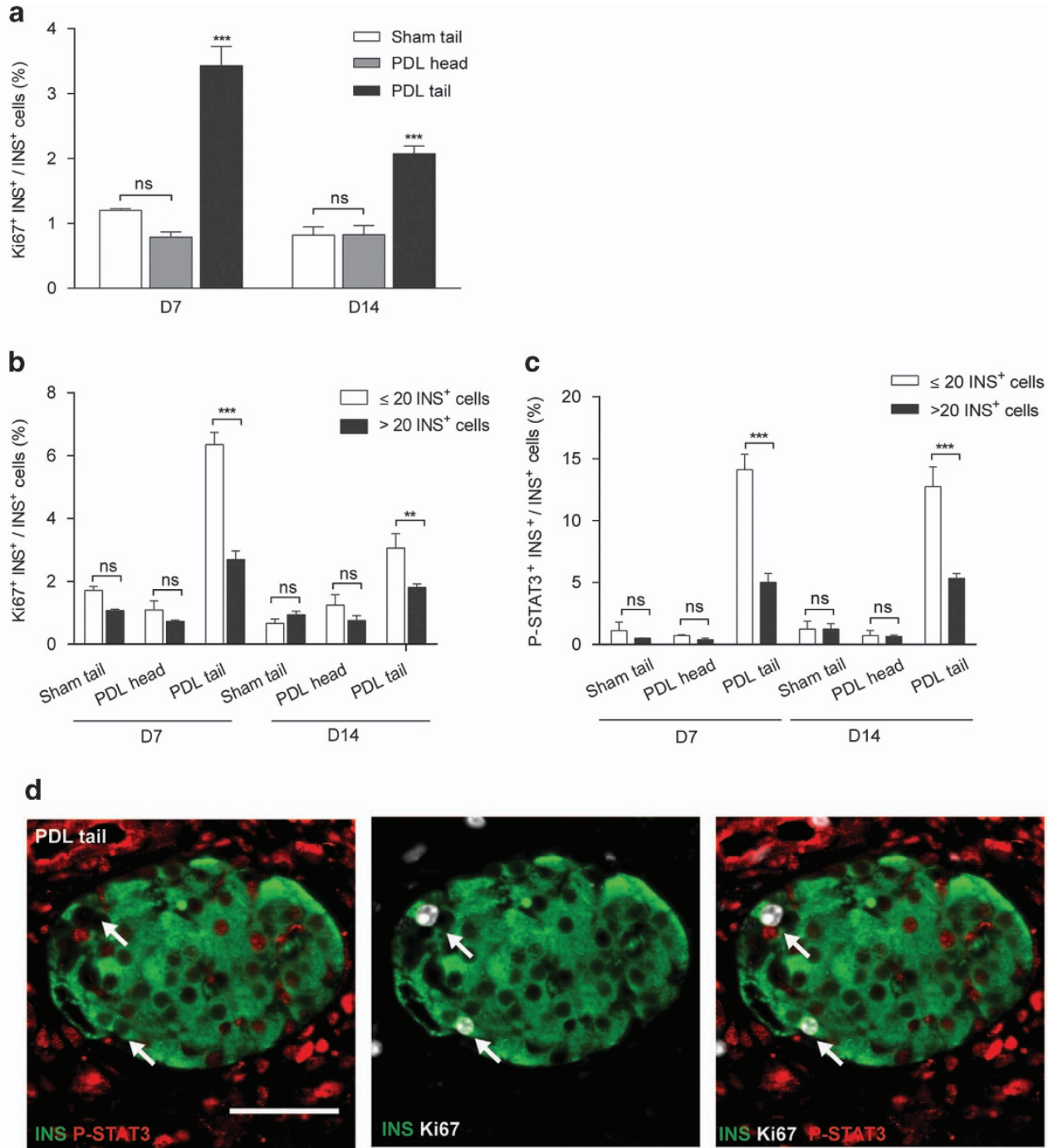

Figure 2 Ki67 $\beta$-cells differ from P-STAT3 ${ }^{+} \beta$-cells in PDL pancreas. (a) $\beta$-Cells with active cell cycle (Ki67 ${ }^{+}$) at D7 and D14 post surgery (mean \pm S.E.M., D7: $n=3$, D14: $n=4-6,{ }^{* \star *} P<0.001$, ns: $P>0.05$, PDL tail versus Sham tail or PDL head by two-way ANOVA). (b) Proliferating $\beta$-cells (Ki67 ${ }^{+}$INS ${ }^{+}$) and (c) $\beta$-cells with activated STAT3 $\left(\mathrm{P}_{-S T A T 3^{+}}\right.$INS $\left.^{+}\right)$cells in small $\left(\leq 20\right.$ INS $^{+}$cells) and large $\left(>20\right.$ INS $^{+}$cells) islets, at D7 and D14 post surgery (mean \pm S.E.M., D7: $n=3, D 14: n=4-6,{ }^{* *} P<0.005$, ${ }^{* * *} P<0.001$, ns: $P>0.05$, small versus large islets in PDL and Sham by unpaired two-tailed $t$-test). (d) Ki67 and P-STAT3 in $\beta$-cells in PDL pancreas. Ki67 ${ }^{+} \beta$-cells are P-STAT3 ${ }^{-}$ (white arrows)

$(n=4, \quad P<0.05)$ and 5.7 -fold in Stat3 ${ }^{-}-$mice $(n=4$, $P<0.005)$ (Figure $3 \mathrm{f}$ ), indicating that STAT3 in $\beta$-cells is dispensable for $\beta$-cell cycling after PDL. Notably, PDL-induced $\beta$-cell cycle was amplified by $70 \%$ in the absence of STAT3 (Figure $3 f)$. As $\mathrm{Ki}^{+} 7^{+} \beta$-cells are most prominent in small islets of PDL tail in WT mice ${ }^{38,39}$ (Figure 2c), increased $\beta$-cell cycling observed in $\mathrm{Stat}^{-/}$pancreas could conceivably be caused by an increased amount of small islets. However, the distribution of small, medium and large islets in Stat3 ${ }^{-/}$ mice was similar to that in the WT mice (Supplementary Figure S4a). $\beta$-Cell cycling was only significantly increased in large islets in Stat $3^{-/}$compared with WT mice. (Figure $3 \mathrm{~g}$ ). Despite this increase, insulin content and $\beta$-cell volume was similar in PDL tail of $\mathrm{Stat}^{-/}$and WT mice (Figures $3 \mathrm{~h}$ and i). The percentage of $\mathrm{Ki}^{-} 7^{+} \alpha$-cells nor the $\alpha$ - to $\beta$-cell ratio were altered in PDL tail of Stat ${ }^{-1}$ compared with WT mice (Supplementary Figures S4b and c).
STAT3 activation by rIL6 lowers $\beta$-cell cycling in PDL pancreas. As IL6 is a potent activator of STAT3, ${ }^{40}$ recombinant mouse IL6 (rIL6) was injected in the tail of D7 PDL pancreas, in order to evaluate the effect of increased STAT3 activation on $\beta$-cell proliferation. As STAT3 protein has a short half-life, ${ }^{41}$ pancreas was collected $1 \mathrm{~h}$ after injection (Figure 4a). $\beta$-Cells $(95 \pm 3 \%)$ contained P-STAT3 in rlL6injected PDL tail as compared with only $13 \pm 5 \%$ following vehicle injection (Figures $4 \mathrm{~b}$ and $\mathrm{c}$ ). Twenty-four hours after rlL6 injection, the percentage of P-STAT3 ${ }^{+} \beta$-cells in PDL tail had returned to baseline (Figure 4d). However, at this time point, the percentage of $\mathrm{Ki} 67^{+} \beta$-cells in rlL6-injected PDL tail was significantly lower when compared with vehicle control (Figure 4e). These data suggest that activation of STAT3 by exogenous IL6 blunts PDL-induced $\beta$-cell cycling. To determine whether endogenous IL6 contributed to STAT3 activation in PDL tail, an IL6-neutralizing antibody was injected in 
Table 2 P-STAT3 ${ }^{+}$proliferating $\beta$-cells in PDL and Sham pancreas

\begin{tabular}{|c|c|c|c|c|c|c|c|c|c|c|c|c|}
\hline & \multicolumn{10}{|c|}{ P-STAT3+ proliferating $\beta$-cells in PDL and Sham pancreas at 7 and 14 days post surgery } & & \\
\hline & \multicolumn{2}{|c|}{ INS+ } & \multicolumn{2}{|c|}{ KI67+INS+ } & \multicolumn{2}{|c|}{ P-STAT+INS+ } & \multicolumn{2}{|c|}{ P-STAT3+KI67+INS+ [Cl] } & \multicolumn{2}{|c|}{$\% \mathrm{KI} 67+$} & \multicolumn{2}{|c|}{ \%P-STAT3+ } \\
\hline & D7 & D14 & D7 & D14 & D7 & D14 & D7 & D14 & D7 & D14 & D7 & D14 \\
\hline PDL tail & 3786 & 4843 & 103 & 123 & 230 & 304 & $(0,0.00051)$ & $(0,0.00040)$ & 2.72 & 2.54 & 6.08 & 6.28 \\
\hline PDL head & 3130 & 3410 & 16 & 21 & 14 & 22 & $(0,0.00061)$ & $(0,0.00056)$ & 0.51 & 0.62 & 0.45 & 0.65 \\
\hline SHAM tail & 3167 & 4928 & 55 & 48 & 19 & 50 & $(0,0.00061)$ & $(0,0.00039)$ & 1.74 & 0.97 & 0.6 & 1.01 \\
\hline
\end{tabular}

Quantification of Ki67+ P-STAT3+ double-positive $\beta$-cells in PDL tail and head, and Sham tail at 7 and 14 days post surgery. INS ${ }^{+}$, number of $\beta$-cells quantified; $\mathrm{Ki}^{+} 7^{+} \mathrm{INS}^{+}$, number of proliferating $\beta$-cells quantified; P-STAT3 ${ }^{+} \mathrm{INS}^{+}$, number of P-STAT3-positive $\beta$-cells; P-STAT3 ${ }^{+} \mathrm{Ki}^{+} 7^{+}$INS ${ }^{+}[\mathrm{CI}]$, number of P-STAT3-positive and Ki67-positive (proliferating) $\beta$-cells and the computed Wilson confidence interval, $n=3$

PDL tail at D6 post surgery. Twenty-four hours after injection, the percentage of $\mathrm{P}_{-S T A T 3}{ }^{+} \beta$-cells in PDL tail was $50 \%$ lower in anti-IL6-injected as compared with isotype-injected pancreas (Figure 4d), indicating that endogenous IL6 contributes to STAT3 activation in $\beta$-cells. However, $\beta$-cell cycling was not significantly increased in anti-IL6-injected PDL tail compared with isotype-injected PDL tail (Figure 4e), suggesting that a $50 \%$ reduction in STAT3 activation in $\beta$-cells is not sufficient to activate the $\beta$-cell cycle as compared with deletion of a functional STAT3 in $90 \%$ of $\beta$-cells. Alternatively, a STAT3mediated delay to initiate $\beta$-cell cycling may have preceded injection of anti-IL6 antibody.

STAT3 protects $\beta$-cells from DNA damage in PDL. As the increased number of cycling $\beta$-cells observed in $\beta$-cellspecific Stat3 ${ }^{-/}$mice was not accompanied by an increase in pancreatic insulin content and $\beta$-cell volume (Figures 3h and i), we hypothesized that $\beta$-cells may be experiencing stress under these conditions. Indeed, the mRNA expression of deleterious cytokines $/ / 1 \mathrm{~b}$, Ifng and $\mathrm{Tnfa}^{42}$ were significantly higher in PDL tail at D3, 7 and 14 following surgery, with the most prominent induction at D7 (Figure 5a). Although $\beta$-cells that expressed the apoptosis marker cleaved caspase 3 could be identified in WT and Stat3 ${ }^{-/}$PDL tail, their percentage was very low ( $<0.1 \%$ of INS+ cells) (Figure $5 b)$. In PDL tail of Stat3 ${ }^{-1}$ mice, the increase in percentage of cleaved caspase $3^{+} \beta$-cells, as compared with WT, was not statistically significant (Figure 5b). However, as late-apoptotic cells are likely to be cleared quickly, we measured levels of the $\beta$-cell death marker miR375 via quantitative reverse transcription PCR in plasma of WT and Stat $^{-1}$ mice at D1-D14 post PDL surgery. MiR375 is a $\beta$-cell-specific microRNA and is discharged in the circulation at levels that are proportionate to the number of necrotic or apoptotic $\beta$-cells. ${ }^{43,44}$ Although miR375 could be detected at all time points following PDL, its level at D1 was highest in Stat3 ${ }^{-/}$ compared with WT mice. These data suggest elevated $\beta$-cell loss in PDL pancreas of Stat3 ${ }^{-/}$mice (Figure $5 \mathrm{c}$ ). To assess DNA damage in $\beta$-cells in PDL pancreas of Stat3 ${ }^{-1-}$ and WT mice, expression of histone $\gamma-\mathrm{H} 2 \mathrm{AX}(\mathrm{gH} 2 \mathrm{AX})$ was investigated. Phosphorylation of $\mathrm{gH} 2 \mathrm{AX}$ at sites of DNA doublestrand breaks aids recruitment of DNA repair factors ${ }^{45}$ and is typified by focal nuclear staining for $\mathrm{gH} 2 \mathrm{AX}$. In contrast, homogenous or pan-nuclear staining for $\mathrm{gH} 2 \mathrm{ax}$ is observed in nuclei of cells with single-strand breaks induced by UV irradiation, during nucleotide excision repair, in DNA fragmentation during apoptosis ${ }^{46}$ but also in nuclei of replicating cells with undamaged DNA. ${ }^{47-49}$ In WT and Stat ${ }^{-/}$PDL, immunostaining for $\mathrm{gH} 2 \mathrm{AX}$ revealed $\beta$-cells whose nuclei either displayed 1 or 2 positive nuclear foci (yellow arrowheads in Figure $5 \mathrm{~d}$ ) and Ki67+ $\beta$-cells whose nuclei displayed homogenous positive nuclear $\mathrm{gH} 2 \mathrm{AX}$ staining (white arrow in Figure $5 \mathrm{~d}$ ). Homogenous staining for $\mathrm{gH} 2 \mathrm{AX}$ was found in approximately half of $\mathrm{Ki}^{+} \beta$-cells in PDL tail $(51 \%$ in Stat $^{-1-}$ and $47 \%$ in WT mice) (Figure 5f). When these cells were excluded from our DNA damage analysis, $\gamma-\mathrm{H}_{2} \mathrm{AX}^{+}$ $\mathrm{Ki}^{-} \beta$-cells were 2.7 -fold more abundant in PDL tail of Stat $^{-/-}$versus WT mice (Figures $5 \mathrm{e}$ and f). The high efficiency of Stat3 deletion (90\%) in Stat3 ${ }^{-/}$mice appeared crucial for the effect on DNA damage, as $50 \%$ inhibition of STAT3 activity by injection of anti-IL6 antibody into PDL pancreas did not affect the percentage of $\mathrm{gH}_{2} \mathrm{AX}^{+} \mathrm{Ki} 67^{-}$ $\beta$-cells (Figure $5 \mathrm{~g}$ ). Conversely, injection of IL6 in order to increase STAT3 activation and diminish DNA damage in PDL pancreas did not significantly affect the percentage of $\mathrm{gH}_{2} \mathrm{AX}^{+} \mathrm{Ki}^{-} 7^{-} \beta$-cells compared with vehicle-injected PDL. These findings suggest that the protective effect of STAT3 on $\beta$-cell DNA integrity may not only depend on IL6-induced activation of STAT3.

\section{Discussion}

STAT3 signaling is dispensable for normal pancreas development but is involved in malignant processes such as acinar-to-ductal metaplasia ${ }^{50}$ and pancreatic ductal adenocarcinoma. ${ }^{36,51}$ PDL induces severe injury resulting in massive loss of exocrine acinar cells and acinar-to-ductal metaplasia, accompanied by local inflammation with infiltration of $\mathrm{CD} 45^{+}$cells and expression of various cytokines and growth factors. ${ }^{21,23-25}$ We previously demonstrated that PDL causes $\beta$-cell mass expansion, in part attributed to proliferation of both pre-existing and newly formed $\beta$-cells. ${ }^{21,38}$ In the present study, we investigated STAT3 activation in PDL and its role in increased $\beta$-cell proliferation.

Activation of STAT3 is induced by factors specific to the PDL environment. ${ }^{21,23-25}$ We identified 20 STAT3-activating factors that are moderately or highly upregulated in ligated pancreas, and that promote Stat3 gene expression and protein activation specifically in $\beta$-cells located in small islets. This preferential localization suggests involvement of STAT3 
signaling in $\beta$-cell proliferation, as the latter is predominantly observed within small islets. In addition, transduction of cultured rat $\beta$-cells with a constitutively active form of STAT3 has been shown to induce a 2.8-fold higher BrdU incorporation rate. ${ }^{52}$ Nevertheless, P-STAT3 and Ki67 did not co-localize in $\beta$-cells of PDL pancreas, irrespective of islet size, whereas

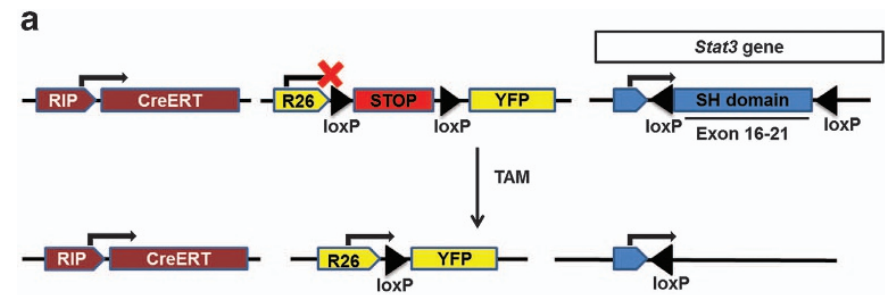

b
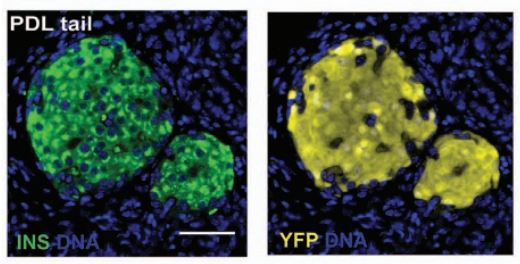

C
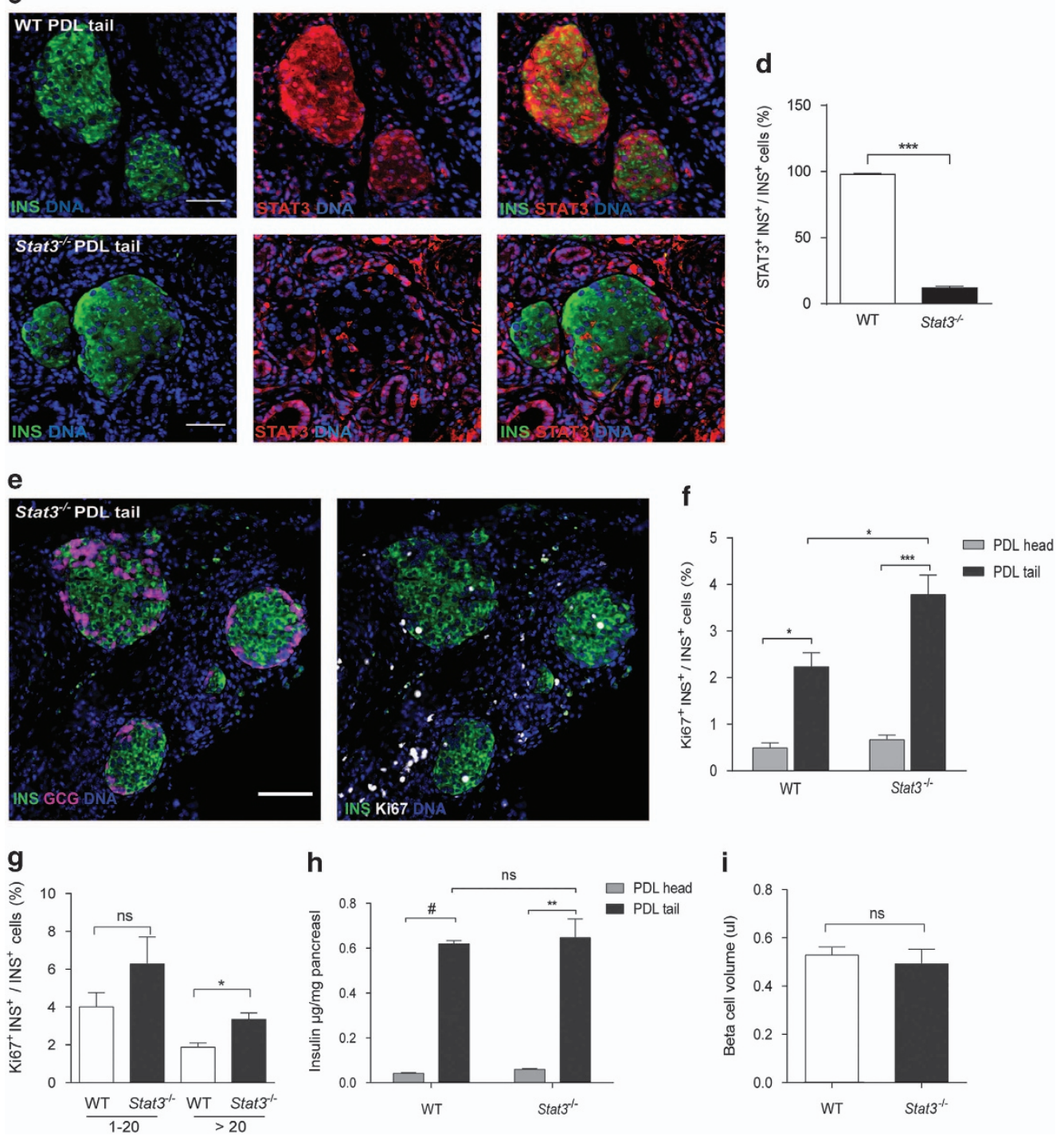
co-localization of Ki67 and P-STAT3 was observed in $a$ - and duct cells, suggesting a direct role for STAT3 in the cell cycle of these latter cell types only.

To address STAT3 function in $\beta$-cells, we generated mice that allow efficient, inducible and $\beta$-cell-specific Stat3 knockout. These mice displayed normal bodyweight and glycemic control, irrespective of PDL. This is in contrast to $R I P^{C r e}$-induced deletion of Stat3 in developing $\beta$-cells and in insulin-expressing hypothalamic neurons - where it disrupts leptin signaling - which results in appetite gain and mild obesity. ${ }^{15,16}$ Together with the fact that Cre expression per se disturbs $\beta$-cell function, ${ }^{53}$ these off-target effects explain why $R I P^{C r e} ;$ Stat3 ${ }^{\text {lox/lox }}$ mice become obese and glucose intolerant. ${ }^{15,16}$ Our data suggest that, within the time frame of our study, that is, 4-5 weeks after recombination, deletion of Stat 3 from adult $\beta$-cells or hypothalamic neurons (as shown by yellow fluorescent protein (YFP) expression by hypothalamic neurons; Supplementary Figure S5) does not interfere with normal physiology and glucose handling. We therefore assume that the effects of STAT3 inactivation in our model are $\beta$-cell specific rather than systemic.

As Stat3-depleted $\beta$-cells still express Ki67 in PDL pancreas, STAT3 signaling seems not to be required for $\beta$-cell cycling. On the contrary, Stat3 deletion from $\beta$-cells increased the percentage of $\mathrm{Ki}^{+} 7^{+} \beta$-cells in PDL pancreas. Consequently, STAT3 appears to inhibit or at least delay the

a

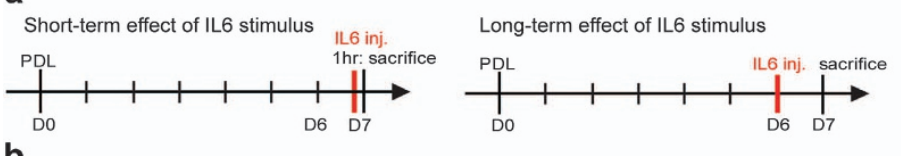

b
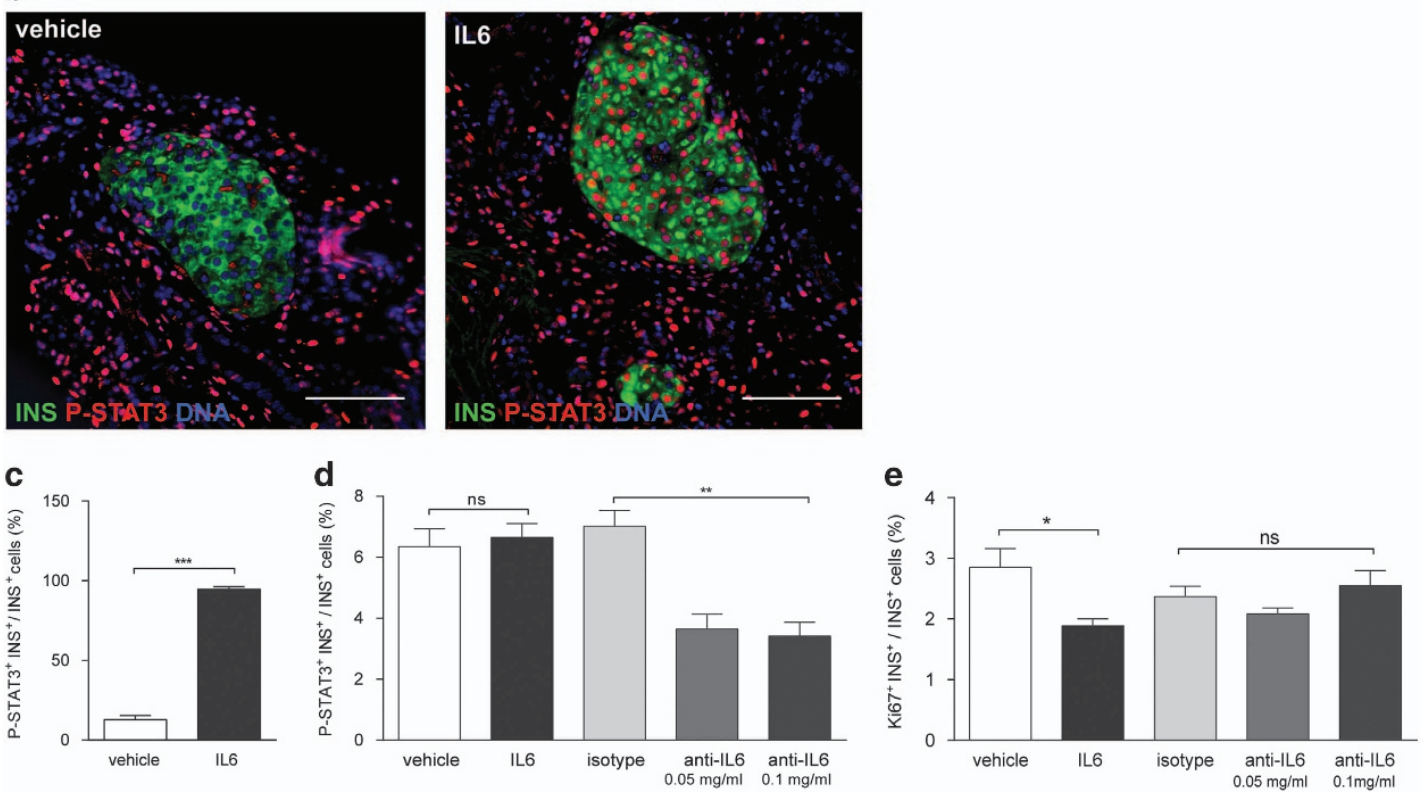

Figure 4 Recombinant IL6 stimulates STAT3 activation and blunts $\beta$-cell cycling in PDL pancreas. (a) Left: short-term effect of recombinant (r) IL6, injected at D7 post surgery into PDL pancreas that was collected $1 \mathrm{~h}$ post injection. Right: long-term effect of recombinant $(r)$ IL 6 injected at D6 post surgery into PDL pancreas that was collected $24 \mathrm{~h}$ post injection. (b) Immunostaining for P-STAT3 and insulin (INS) in PDL tail pancreas $1 \mathrm{~h}$ after (r)IL6 or vehicle injection at D7 post PDL. (c) Percentage of P-STAT3 ${ }^{+} \beta$-cells in PDL tail $1 \mathrm{~h}$ after vehicle or (r) LL6 injection (mean \pm S.E.M., $n=4$, ${ }^{\star \star \star} P<0.001$, vehicle versus (r) IL6-injected PDL tail pancreas, by unpaired two-tailed t-test). (d) Percentage P-STAT ${ }^{+}$ $\beta$-cells $24 \mathrm{~h}$ after vehicle, $(r)$ IL6, isotype or anti-IL6 injection in PDL tail at D7 post PDL $\left(n=4,{ }^{* *} P<0.005, n s: P>0.05\right.$, vehicle versus (r) IL6-injected PDL tail pancreas and isotype versus anti-IL6-injected PDL pancreas, two-way ANOVA). (e) Cycling $\beta$-cells (Ki67 INS ${ }^{+}$) in PDL tail injected with vehicle, (r)IL6, isotope or anti-IL6 at D7 post surgery (mean \pm S.E.M., $n=4,{ }^{*} P<0.05$, ns: $P>0.05$, vehicle versus (r)IL6-injected PDL tail pancreas and isotype versus anti-IL6-injected PDL pancreas, two-way ANOVA)

Figure $3 \beta$-Cell-specific Stat3 knockout stimulates $\beta$-cell cycling after PDL. (a) Schematic illustration of the inducible transgenic mouse model, RIP (rat insulin gene promotor), CreERT (causes recombination fused to TAM-inducible estrogen receptor), R26 (Rosa26 promotor), loxP (locus of crossing over P1), STOP (transcriptional STOP sequence), YFP, TAM. (b) Recombination efficiency as shown by immunostaining for YFP in INS+ cells in PDL tail of RipCre ${ }^{\text {ERT }}$ R26 ${ }^{\text {YFP }}$ mouse. (c) Immunostaining for STAT3 in PDL tail from WT versus Stat $3^{-1}$ mice, quantified in (d) as the percentage of STAT3 ${ }^{+}$INS $^{+}$cells in PDL tail from WT and Stat3 ${ }^{-/}$mice. (e) Cycling $\beta$-cells (Ki67 $7^{+}$INS ${ }^{+}$) were observed in the islets of Stat $3^{-1-}$ mice that appeared normal based on the distribution of $\beta$ - and $\alpha$-cells (GCG ${ }^{+}$). (f) $\beta$-Cell cycling (Ki67 INS ${ }^{+}$) in PDL head and tail pancreas from WT and Stat ${ }^{-1-}$ mice at D14 post surgery. (g) Percentage INS ${ }^{+}$cells that express Ki67 $7^{+}$, in small ( $\leq 20$ INS $^{+}$cells) and large $\left(>20\right.$ INS ${ }^{+}$cells) islets of PDL head and tail pancreas from WTand Stat $3^{-1-}$ mice at D14 post surgery. (h) Total insulin content ( $\mu$ g insulin per mg tissue) in PDL head and tail pancreas from WT and Stat3 ${ }^{-/-}$mice. (i) $\beta$-Cell volume $(\mu l)$ in PDL tail pancreas from WTand Stat3 ${ }^{-/}$mice. (d and f-i) mean \pm S.E.M., in (d and $\mathbf{f}-\mathbf{h}$ ) $n=4$, in (i) $n=3-4,{ }^{*} P<0.05,{ }^{* \star} P<0.005,{ }^{* \star *} P<0.001,{ }^{\#} P<0.0001$, ns: $P>0.05$, WT versus Stat ${ }^{-/-}$by unpaired two-tailed $t$-test 
initiation of the $\beta$-cell cycle in injured pancreas. In-depth analysis of STAT3 activation dynamics and activation of the $\beta$-cell cycle is required to define this inhibition or delay and its effects. A similar role for STAT3 in growth arrest has been identified in monocytes. ${ }^{40}$ In addition, in T-lymphocytes, STAT3 inhibits the proliferative response to IL-2, ${ }^{54}$ whereas
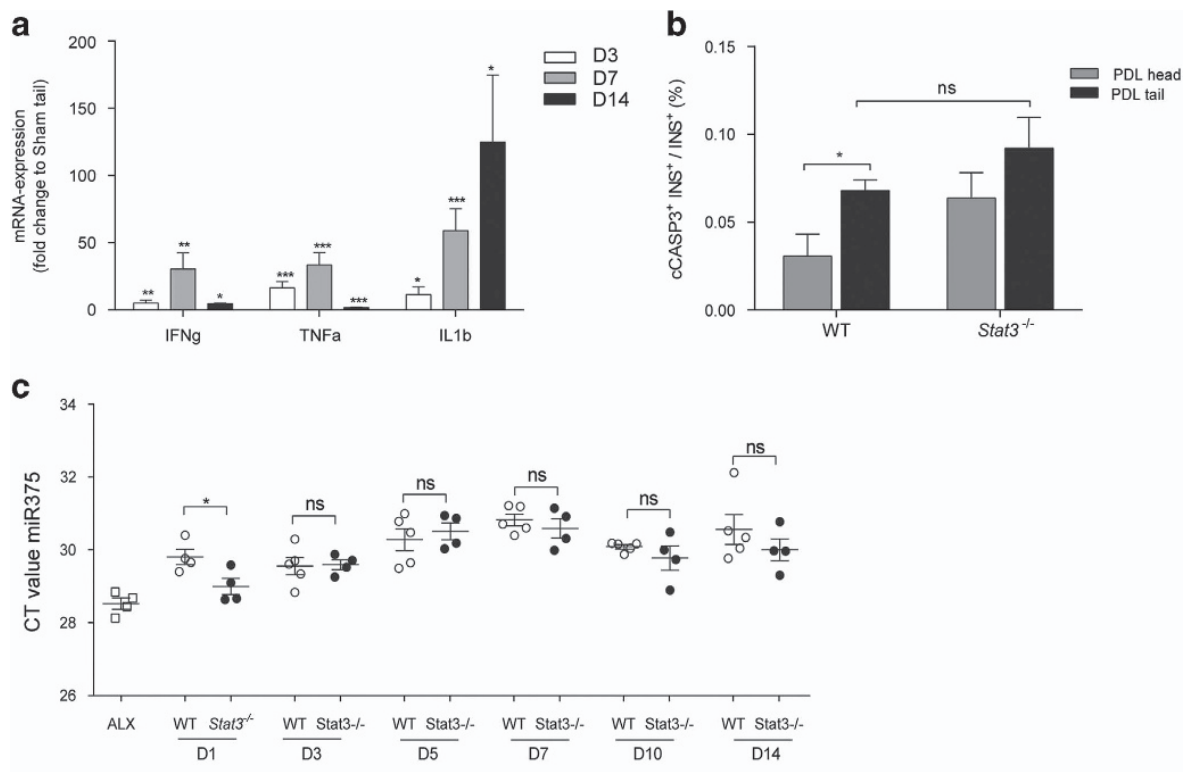

d
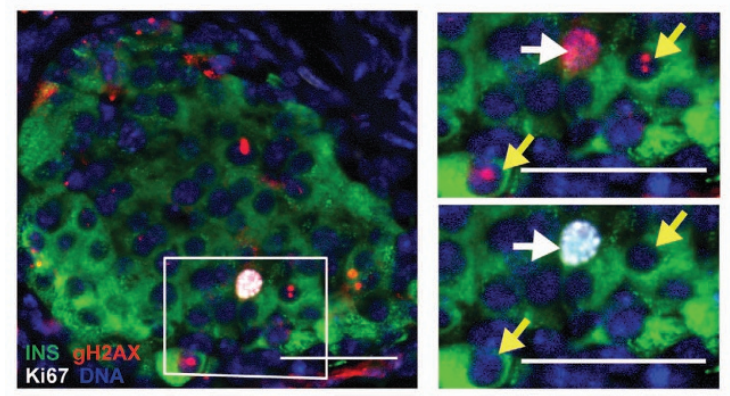

e
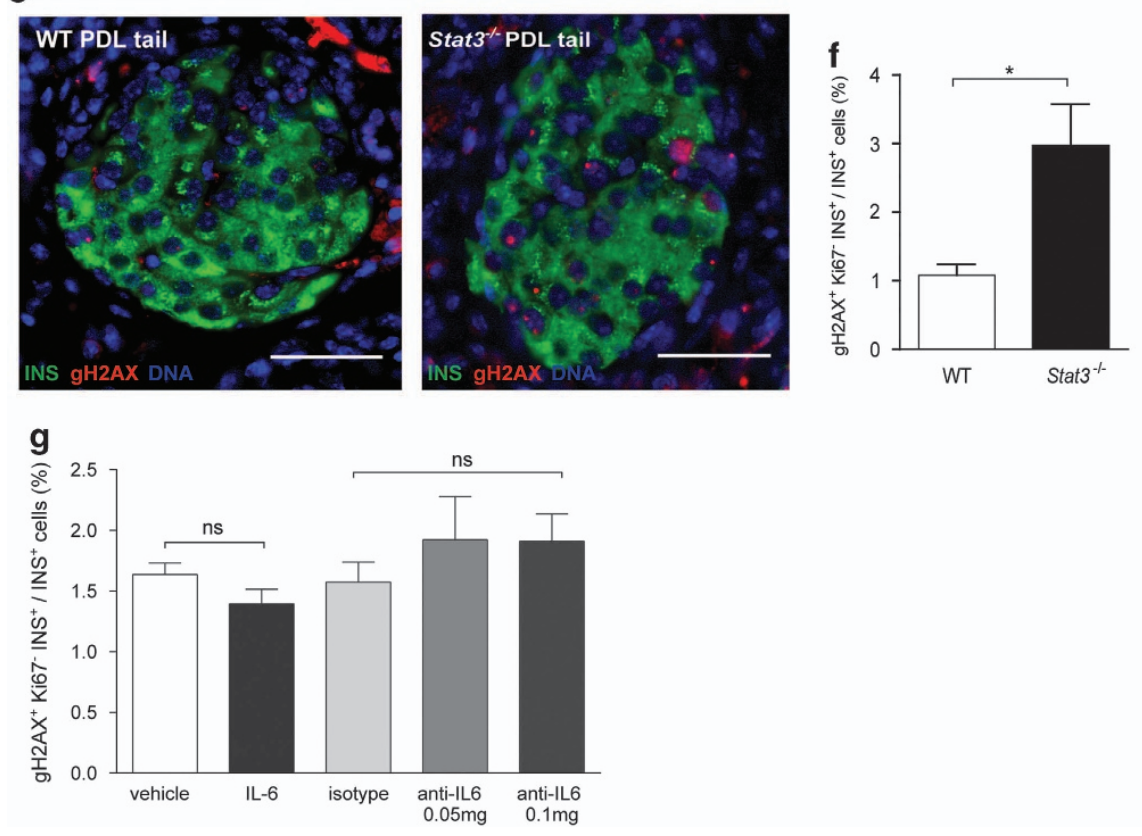
IL6-mediated activation of STAT3 inhibits hepatocyte proliferation $^{55}$ and growth of carcinoma and myeloid leukemia cells. ${ }^{40}$ As the percentage of $\mathrm{Ki}^{+} 7^{+} \beta$-cells did not increase in PDL head of pancreas in Stat $3^{-/}$mice, cytokines or growth factors produced locally in PDL tail may signal via STAT3 and prevent excessive $\beta$-cell proliferation specifically in PDL tail. As a higher number of $\beta$-cells in small islets, a hotspot for $\beta$-cell proliferation after PDL, displayed STAT3 activation, we assume that STAT3 limits or delays excessive $\beta$-cell cycling in pro-proliferative environments. Stat3 deletion allowed increased $\beta$-cell proliferation, mainly in large islets. Possibly, activation of $\beta$-cell division in Stat $^{-/}$mice was less pronounced in small islets, because this location already is a privileged site for $\beta$-cell division. It is also a site where new STAT3-competent $\beta$-cells are formed by differentiation, thus escaping Stat3 deletion that was induced in pre-existing $\beta$-cells before surgery. ${ }^{38}$

Increased $\beta$-cell cycling without an associated increase in insulin content and $\beta$-cell volume in PDL pancreas of Stat3 ${ }^{-/}$ mice suggests that not all actively cycling $\beta$-cells complete their cell cycle. However, the percentage $\mathrm{Ki}^{+} 7^{+} \beta$-cells that contain the G2-M marker phosphohistone $\mathrm{H} 3$ was $30 \%$ in both Stat $^{-/}$and WT mice (data not shown). By consequence, increased $\beta$-cell death in PDL pancreas of Stat3 ${ }^{-/}$mice is an alternative explanation for increased $\beta$-cell cycling without a concomitant increase in $\beta$-cell volume. An increase in $\beta$-cell death was demonstrated by analysis of plasma miR-375 levels early after PDL in Stat3 ${ }^{-/}$mice.

Exposure to the pro-inflammatory cytokines IL1b and IFNg that both are present in PDL pancreas, causes nitric oxidemediated DNA damage in $\beta$-cells that contain reduced amounts of insulin and display suppressed glucosestimulated insulin secretion. ${ }^{56,57}$ The cytokine-induced DNA damage that is characterized by an increased number of $\beta$-cells with phosphorylated $\mathrm{gH} 2 \mathrm{AX}$ leads to $\beta$-cell death. ${ }^{58}$ The percentage of $\beta$-cells expressing gH2AX was significantly increased in mice with $\beta$-cell-specific Stat ${ }^{-/}$. Therefore, STAT3 may serve as (part of) a mechanism to secure DNA integrity before cell cycling. In regenerating liver, STAT3 lowers hepatocyte cycling by increased expression of p21 Cip1,55 coinciding with the upregulation of several DNA repair enzymes. ${ }^{59}$ Mice that undergo PDL harbor increased levels of inflammatory cytokines in the PDL tail, while displaying normal glycemic control and only low numbers of apoptotic (cleaved caspase $3^{+}$) $\beta$-cells, indicative for a very tight regulation and protection of $\beta$-cells from these deleterious factors. Protection from cytokine-induced $\beta$-cell apoptosis has been described for CNTF and humanin, signaling through
STAT3. ${ }^{60,61}$ We hypothesize the existence of a similar protective role for STAT3 against inflammatory cytokines in PDL.

To further support our observations in Stat3 knockout mice, we injected recombinant IL6 into the ligated part of the pancreas, thereby efficiently boosting local STAT3 signaling in $\beta$-cells, as acinar atrophy and shrinkage of the tissue allows for easy diffusion of the cytokines. Increased activation of STAT3 was sufficient to blunt PDL-induced activation of $\beta$-cell cycling, similar to regenerating liver. ${ }^{55}$ DNA damage, however, did not decrease on IL6 injection, likely because basal DNA damage in $\beta$-cells is as low as $1.6 \%$ in G0 $\beta$-cells of PDL pancreas. In addition, IL6-activated STAT3 can be negatively regulated by SOCS3 that inhibits JAK activation by binding to gp130 through its $\mathrm{SH} 2$ domain. $\beta$-Cell-specific Socs3 knockout maintains STAT3 activation and, consequently, the expression of $B c /-x L$ that reduces streptozotocin-induced toxicity and apoptosis. ${ }^{62}$ In PDL pancreas, STAT3 activation may be short term and its signaling may be inhibited through negative feedback by SOCS3. ${ }^{60}$ The abundance of STAT3 appears crucial, as a $50 \%$ reduction by anti-IL6 injection was insufficient to increase $\beta$-cell cycling or DNA damage in PDL pancreas, as compared with the $90 \%$ reduction in Stat ${ }^{-/}$ mice. Factors other than IL6 may thus contribute to the control of STAT3 activity in $\beta$-cells in ligated pancreas. Other potential STAT3-activating factors that are increased in PDL pancreas and for which receptors are expressed by $\beta$-cells include CNTF, ${ }^{60}$ Leptin, ${ }^{63}$ IL 10, ${ }^{64}$ HGF, ${ }^{65}$ IGF $^{66}$ and PDGF. ${ }^{67}$ Although these factors potentially modulate STAT3 in $\beta$-cells in PDL pancreas, still many other cytokines and signaling pathways may participate in the regulation of $\beta$-cell proliferation and survival in PDL. Therefore, PDL offers an interesting tool for the identification of signaling pathways and factors that influence $\beta$-cell survival and growth in an inflammatory environment.

In conclusion, our data indicate that STAT3 protects $\beta$-cells from excessive cell cycling and from deleterious effects exerted by cytokines that are inherent to the inflammatory environment of duct-ligated pancreas.

\section{Materials and Methods}

Animals. All experiments were performed in accordance with the guidelines of the ethical committee of the Vrije Universiteit Brussel. Mice were housed in microisolator cages, maintained on a $12 / 12 \mathrm{~h}$ light-dark cycle and fed a standard rodent diet.

Mouse manipulation. PDL was performed as described ${ }^{21,68}$ on 8- to 9-weekold male mice. For IL6 and anti-IL6 intrapancreas injection, 8-week-old BALB/cJRj

Figure 5 STAT3 protects $\beta$-cells from DNA damage in PDL pancreas. (a) Abundance of mRNA encoding inflammatory cytokines (Ifng, Tnfa and I/1b) in PDL tail. Data are expressed as fold change compared with transcript level in Sham tail (1) (D3: $n=4, \mathrm{D} 7: n=4, \mathrm{D} 14: n=3,{ }^{*} P<0.05,{ }^{\star \star} P<0.005,{ }^{* \star \star} P<0.001$, ${ }^{\sharp} P<0.0001$, ns: $P>0.05$, Sham tail versus PDL tail by unpaired two-tailed $t$-test). (b) Percentage $\beta$-cell apoptosis (cCASP3 ${ }^{+}$INS ${ }^{+}$) in PDL head and tail pancreas from WT and Stat3 ${ }^{-1-}$ mice at D14 post surgery $\left(n=4,{ }^{*} P<0.05\right.$, ns: $P>0.05$, WT versus Stat3 ${ }^{-1}$, two way ANOVA). (c) Abundance of miR375 in plasma from WTand Stat3 ${ }^{-1}$ mice at D1, D3, D5, D7, D10 and D14 post PDL surgery and in plasma of positive control for $\beta$-cell death $24 \mathrm{~h}$ after Alloxan injection (ALX). Data are expressed as Ct values. WT, $n=5 ;$ Stat3 ${ }^{-1-}, n=4 ;{ }^{*} P<0.05, n s: P>0.05$, WT versus Stat $3^{-1}$ by unpaired two-tailed $t$-test) (d) Immunostaining for Ki67 and gH2AX in PDL tail pancreas from Stat3 ${ }^{-1}$ mice showing two forms of gH2AX nuclear staining: homogenous nuclear labeling in proliferating $\beta$-cells (white arrows) and nuclear foci (yellow arrows). (e) gH2AX in PDL tail from WT and Stat3 ${ }^{-1}$ mice at D14 post surgery. (f) Percentage non-cycling $\beta$-cells with DNA damage $\left(\mathrm{gH} 2 \mathrm{AX}{ }^{+} \mathrm{Ki}_{67}{ }^{-} \mathrm{INS} \mathrm{S}^{+}\right)$in PDL tail from WTand Stat3-- mice at D14 post surgery $\left(n=4,{ }^{*} P<0.05\right.$, ns: $P>0.05$, WT versus Stat $^{-1}$, by unpaired two-tailed $t$-test). (g) Percentage non-cycling $\beta$-cells with DNA damage (gH2AX+ Ki67 $\left.{ }^{-} \mathrm{INS}^{+}\right)$in PDL tail pancreas injected with vehicle, (r)IL6, isotype or anti-IL6 at D7 post surgery $\left(n=4,{ }^{*} P<0.05\right.$, ns: $P>0.05$, two-way ANOVA) 
male mice (Janvier, Saint Berthevin, France) were anesthetized by i.p. injection of $3.5 \mathrm{mg}$ ketamine $+0.5 \mathrm{mg}$ xylazine per $\mathrm{kg}$ bodyweight. The ligated pancreas was exposed through a lateral incision and injected with either $30 \mu \mathrm{l}$ of $0.1 \mathrm{mg} / \mathrm{ml}$ carrierfree rlL6 (R\&D Systems, Minneapolis, MN, USA), vehicle $(0.9 \% \mathrm{NaCl}), 0.1$ or $0.05 \mathrm{mg} / \mathrm{ml}$ anti-IL6 (clone MP520F3, Hycult Biotech, Uden, The Netherlands) or rat IgG (Vector Laboratories, Burlingame, CA, USA). TAM (Sigma-Aldrich, St. Louis, MO, USA) was prepared and administered as described. ${ }^{38}$

$\boldsymbol{\beta}$-Cell-specific Stat3 knockout mice. $\beta$-Cell-specific Stat3 knockout mice were generated by crossing $R I P^{C r e E R} ; R 26^{Y F P}$ mice with Stat ${ }^{\text {loxlox }}$ mice. RIP CreER; $R 26^{Y F P}$ mice express a fusion protein of Cre recombinase and a mutated TAM responsive estrogen receptor under control of the rat insulin promoter (RIP) in addition to conditional YFP reporter expression under control of the Rosa26 promotor (R26). ${ }^{69}$ In Stat3 ${ }^{\text {lox/lox }}$ mice, exon 16-21 encoding the SH-domain of the STAT3 protein is flanked by loxP sites. As control mice, CreER-deficient Stat3 ${ }^{\text {lox/lox }}$ littermates were used. Genotyping was performed on tail snips using primers for $\mathrm{Cre}$ (forward 5'-CCTGTTTTGCACGTTCACCG-3', reverse 5'-ATGCTTCTGTCCGTTT GCCG-3'), YFP (forward 5'-AAAGTCGCTCTGAGTTGTTA-3', reverse 5'-GGAGC GGGAGAAATGGATATG-3'), splice acceptor (5'-CATCAAGGAAACCCTGGACTACT $-3^{\prime}$ ) and for the Stat3 floxed allele (forward 5'-ATTGGAACCTGGGACCAAGTG-3', reverse $5^{\prime}$-ACATGTACTTACAGGGTGTGT-3'). RIPCre ${ }^{\text {ERT }}$;R26 $6^{\text {YFP }}$; Stat ${ }^{\text {lox/lox }}$ mice or WT RIPCre ${ }^{E R T}$ negative littermates received $4 \mathrm{mg}$ TAM, repeated once every other day, for five injections in total, followed by a 14-day washout period and PDL surgery. PDL head and PDL tail was collected 14 days post surgery.

Metabolic follow-up. Mice were fasted for $2 \mathrm{~h}$ before measurement of glycemia. For IPGTT, mice were fasted for $16 \mathrm{~h}$ before i.p. injection with glucose ( $2 \mathrm{~g}$ per $\mathrm{kg}$ body weight). Blood glucose concentration was measured from tail vein blood with a portable glucometer (Glucomen Lx Plus, Menarini, Florence, Italy). Total pancreas insulin content was determined using a mouse insulin radioimmunoassay kit (Linco Research, St. Charles, MO, USA).

RNA analysis. PDL and Sham tissues were dissociated to single cells using collagenase $(0.8 \mathrm{mg} / \mathrm{ml}$, Sigma-Aldrich) and trypsin ( $1 \mathrm{mg} / \mathrm{ml}$, Sigma-Aldrich), passed through a $66-\mu \mathrm{m}$ filter and resuspended in isolation medium (Lonza, Basel, Switzerland). $\beta$-Cells were isolated by sorting on a FACSDiva 6.0 (Becton Dickinson, Franklin Lakes, NJ, USA) RFP' ${ }^{+}$cells from PDL'ed MIP ${ }^{\text {mRFP }}$ mice followed by a second round of sorting using $\mathrm{Zn}^{2+}$ chelator 6-methoxy-8-p-toluenesulfonamido-quinolone (Thermo Fisher Scientific, Waltham, MA, USA) as $\beta$-cell probe. Total RNA was isolated from cells (RNeasy, Qiagen, Venlo, The Netherlands) or tissue (TRIzol, Thermo Fisher). RNA analysis of cells or tissue was as described, ${ }^{38}$ using primers listed in Supplementary Table S1.

Protein analysis. Samples for immunostaining were fixed overnight at $4{ }^{\circ} \mathrm{C}$ in $10 \%$ neutral buffered formalin, embedded in paraffin and sectioned at $5 \mu \mathrm{m}$. Primary antibodies used were guinea pig polyclonal anti-insulin and rabbit polyclonal anti-glucagon (Diabetes Research Center, Vrije Universiteit Brussel, Brussels, Belgium), rabbit polyclonal anti-Ki67 (eBioscience, San Diego, CA, USA), rat polyclonal anti KRT19 (Developmental Studies Hybridoma Bank, University of lowa, lowa City, IA, USA), rabbit monoclonal anti-phosphoSTAT3 (P-STAT3) (phospho Y705) and anti- $\gamma$ H2AX (gH2AX) (phospho S139), goat polyclonal antiGFP, rabbit polyclonal anti-cleaved caspase3 (Asp175) (all from Abcam, Cambridge, UK) and mouse monoclonal anti-STAT3 (Cell Signaling Technology, Danvers, MA, USA), Staining for GFP, KRT19, glucagon, P-STAT3, STAT3 and gH2AX required heat-mediated antigen retrieval with $10 \mathrm{mM}$ citrate pH 6.0. Cyanine- and AlexaFluorlabeled secondary antibodies were from Jackson ImmunoResearch, Newmarket, UK. Nuclei were stained with Hoechst 33342. Images were acquired with a BX-UCB fluorescence microscope (Olympus, Tokyo, Japan) equipped with an Orca $r^{2}$ camera (Hamamatsu Photonics, Hamamatsu, Japan). Images were analyzed with SmartCapture 3 (Digital Scientific UK, Cambridge, UK). $\beta$-Cell proliferation, STAT3 activation, $\beta$-cell apoptosis and DNA damage in $\beta$-cells were analyzed by determining the proportion of insulin-positive cells co-expressing Ki67, phosphoSTAT3, cleaved caspase-3 or gH2AX, respectively. At least $2000 \beta$-cells were quantified per sample. Quantification was done by manual counting using the cell counter plugin and SmartCaptureLite plugin (Digital Scientific UK) in ImageJ (NIH, Bethesda, MA, USA). The total $\beta$-cell volume was analyzed as previously described. 21,38,70 Images were captured with an inverted microscope (Nikon Instruments, Amstelveen, The Netherlands) equipped with a Hamamatsu digital camera c10600 (Olympus) or with a multiphoton microscope (LSM710 NLO with a
TiSa laser, Zeiss, Thornwood, NY, USA) and analysed using Smartcapture 3 (version 3.0.8) NIS AR2.30 Imaging Software (Nikon France, Champigny-sur-Marne, France) or Improvision Volocity LE (version 5.0) (PerkinEImer, Waltham, MA, USA) and ImageJ software (https://imagej.nih.gov/ij/). ${ }^{71}$

miR375 analysis in plasma. Plasma was obtained from tail vein blood from adult WT and Stat3 ${ }^{-/}$mice at D1, D3, D5, D7, D10 and D14 post PDL surgery. Analysis of miR375 was performed as described by Roels et al. ${ }^{72}$ (In preparation).

Statistical analysis. Data were analyzed using GraphPad Prism 5 (GraphPad Software, San Diego, CA, USA) and are expressed as mean \pm S.E.M. of at least three independent experiments. Data were analyzed by unpaired two-tailed Student's t-test or with one-way or two-way ANOVA with Bonferroni post-hoc test and were considered statistically significant when $P<0.05$. To determine the confidence interval for the proportion of P-STAT $3^{+} \mathrm{Ki}^{+} \mathrm{T}^{+} \beta$-cells, the Wilson score confidence interval was used. Wilson scores have coverage probabilities close to the nominal confidence level, also for small samples sizes or extreme frequencies close to zero.

\section{Conflict of Interest}

The authors declare no conflict of interest.

Acknowledgements. We thank Dr Bin Gao (NIH, Laboratory of Liver Diseases, Bethesda, MA, USA) for providing STAT3lox:lox mice, and Ann Demarré, Veerle Laurysens, Jan De Jonge, Erik Quartier and Gaby Schoonjans for technical assistance. Financial support was from the Fund for Scientific Research Flanders $(\mathrm{HH}, \mathrm{SDG}$ and LB), Universitaire Stichting van België, Interuniversity Attraction Pole network VII-P07 DevRepair $(\mathrm{HH})$, Stichting Diabetes Onderzoek Nederland $(\mathrm{HH})$ and Vrije Universiteit Brussel Research Council (HH and MVdC). LB is supported by a JDRF Advanced Postdoctoral Grant.

\section{Author contributions}

All authors made substantial contributions to conception and design, acquisition or interpretation of data and to drafting and revising the article. $\mathrm{HH}$ and $\mathrm{MVdC}$ provided final approval of the version to be published.

1. Levy DE, Darnell JE Jr. Stats: transcriptional control and biological impact. Nat Rev Mol Cell Biol 2002; 3: 651-662.

2. Levy DE, Lee C-K. What does Stat3 do? J Clin Invest 2002; 9: 1143-1148.

3. Kisseleva T, Bhattacharya S, Braunstein J, Schindler CW. Signaling through the JAK/STAT pathway, recent advances and future challenges. Gene 2002; 285: 1-24.

4. Sano S, Itami S, Takeda K, Tarutani M, Yamaguchi Y, Miura H et al. Keratinocyte-specific ablation of Stat3 exhibits impaired skin remodeling, but does not affect skin morphogenesis. EMBO J 1999; 18: 4657-4668.

5. Kira M, Sano S, Takagi S, Yoshikawa K, Takeda J, Itami S. STAT3 deficiency in keratinocytes leads to compromised cell migration through hyperphosphorylation of p130(cas). J Biol Chem 2002; 277: 12931-12936.

6. Pickert G, Neufert C, Leppkes M, Zheng Y, Wittkopf N, Warntjen M et al. STAT3 links IL-22 signaling in intestinal epithelial cells to mucosal wound healing. J Exp Med 2009; 206: 1465-1472.

7. Takeda K, Kaisho T, Yoshida N, Takeda J, Kishimoto T, Akira S. Stat3 activation is responsible for IL-6-dependent T cell proliferation through preventing apoptosis: generation and characterization of T cell-specific Stat3-deficient mice. J Immunol 1998; 161: 4652-4660.

8. Chapman RS, Lourenco PC, Tonner E, Flint DJ, Selbert S, Takeda K et al. Suppression of epithelial apoptosis and delayed mammary gland involution in mice with a conditional knockout of Stat3. Genes Dev 1999; 13: 2604-2616.

9. Alonzi T, Maritano D, Gorgoni B, Rizzuto G, Libert C, Poli V. Essential role of STAT3 in the control of the acute-phase response as revealed by inducible gene inactivation [correction of activation] in the liver. Mol Cell Biol 2001; 21: 1621-1632.

10. Takeda K, Clausen BE, Kaisho T, Tsujimura T, Terada N, Forster I et al. Enhanced Th1 activity and development of chronic enterocolitis in mice devoid of Stat3 in macrophages and neutrophils. Immunity 1999; 10: 39-49.

11. Schweizer U, Gunnersen J, Karch C, Wiese S, Holtmann B, Takeda K et al. Conditional gene ablation of Stat3 reveals differential signaling requirements for survival of motoneurons during development and after nerve injury in the adult. J Cell Biol 2002; 156: 287-297.

12. Kostromina E, Gustavsson N, Wang X, Lim CY, Radda GK, Li C et al. Glucose intolerance and impaired insulin secretion in pancreas-specific signal transducer and activator of transcription-3 knockout mice are associated with microvascular alterations in the pancreas. Endocrinology 2010; 151: 2050-2059. 
13. Lee J-Y, Henninghausen $L$. The transcription factor Stat3 is dispensable for pancreatic beta cell development and function. Biochem Biophys Res Commun 2005; 334: 764-768.

14. Kostromina $E$, Wang $X$, Han W. Altered islet morphology but normal islet secretory function in vitro in a mouse model with microvascular alterations in the pancreas. PLOS ONE 2013; 8 : e71277.

15. Cui Y, Huang L, Elefteriou F, Yang G, Shelton JM, Giles JE et al. Essential role of STAT3 in body weight and glucose homeostasis. Mol Cell Biol 2004; 24: 258-269.

16. Gorogawa S, Fujitani Y, Kaneto H, Hazama Y, Watada H, Miyamoto Y et al. Insulin secretory defects and impaired islet architecture in pancreatic beta-cell-specific STAT3 knockout mice. Biochem Biophys Res Commun 2004; 319: 1159-1170.

17. Dor Y, Brown J, Martinez OI, Melton DA. Adult pancreatic beta-cells are formed by selfduplication rather than stem-cell differentiation. Nature 2004; 429: 41-46.

18. Teta M, Rankin MM, Long SY, Stein GM, Kushner JA. Growth and regeneration of adult beta cells does not involve specialized progenitors. Dev Cell 2007; 12: 817-826.

19. Brennand K, Huangfu D, Melton D. All beta cells contribute equally to islet growth and maintenance. PLOS Biol 2007; 5: e163.

20. Salpeter SJ, Klein AM, Huangfu D, Grimsby J, Dor Y. Glucose and aging control the quiescence period that follows pancreatic beta cell replication. Development 2010; 137: 3205-3213.

21. Xu X, D'Hoker J, Stange G, Bonne S, De Leu N, Xiao X et al. Beta cells can be generated from endogenous progenitors in injured adult mouse pancreas. Cell 2008; 132: 197-207.

22. Van de Casteele M, Leuckx G, Yuchi Y, Cai Y, Coppens V, Heimberg H. Neurogenin3+ cells directly contribute to new beta cells that preferntially and rapidly cycle in injured adult mouse pancreas. Cell Death Dis 2013; 4: 1-11.

23. Wang RN, Rehfeld JF, Nielsen FC, Kloppel G. Expression of gastrin and transforming growth factor-alpha during duct to islet cell differentiation in the pancreas of duct-ligated adult rats. Diabetologia 1997; 40: 887-893.

24. Yasuda H, Kataoka K, Ichimura H, Mitsuyoshi M, lida T, Kita M et al. Cytokine expression and induction of acinar cell apoptosis after pancreatic duct ligation in mice. $J$ Interferon Cytokine Res 1999; 19: 637-644.

25. Xiao X, Wiersch J, El-Gohary Y, Guo P, Prasadan K, Paredes J et al. TGFbeta receptor signaling is essential for inflammation-induced but not beta-cell workload-induced beta-cell proliferation. Diabetes 2012; 62: 1217-1226.

26. Nielsen JH, Galsgaard ED, Moldrup A, Friedrichsen BN, Billestrup N, Hansen JA et al. Regulation of beta-cell mass by hormones and growth factors. Diabetes 2001; 50 (Suppl 1): S25-S29.

27. Hakonen E, Ustinov J, Mathiis I, Palgi J, Bouwens L, Miettinen PJ et al. Epidermal growth factor (EGF)-receptor signalling is needed for murine beta cell mass expansion in response to high-fat diet and pregnancy but not after pancreatic duct ligation. Diabetologia 2011; 54: 1735-1743.

28. Williams K, Abanquah D, Joshi-Gokhale S, Otero A, Lin H, Guthalu NK et al. Systemic and acute administration of parathyroid hormone-related peptide(1-36) stimulates endogenous beta cell proliferation while preserving function in adult mice. Diabetologia 2011; 54 2867-2877.

29. Choi SE, Choi KM, Yoon IH, Shin JY, Kim JS, Park WY et al. IL-6 protects pancreatic islet beta cells from pro-inflammatory cytokines-induced cell death and functional impairment in vitro and in vivo. Transpl Immunol 2004; 13: 43-53.

30. Rezende LF, Santos GJ, Carneiro EM, Boschero AC. Ciliary neurotrophic factor protects mice against streptozotocin-induced type 1 diabetes through SOCS3: the role of STAT1/ STAT3 ratio in beta-cell death. J Biol Chem 2012; 287: 41628-41639.

31. Jimenez-Gonzalez M, Jaques F, Rodriguez S, Porciuncula A, Principe RM, Abizanda G et al. Cardiotrophin 1 protects beta cells from apoptosis and prevents streptozotocin-induced diabetes in a mouse model. Diabetologia 2013; 56: 838-846.

32. Xu AJ, Zhu W, Tian F, Yan LH, Li T. Recombinant adenoviral expression of IL-10 protects beta cell from impairment induced by pro-inflammatory cytokine. Mol Cell Biochem 2010; 344: 163-171.

33. Fujimoto H, Hirase T, Miyazaki Y, Hara H, Ide-Iwata N, Nishimoto-Hazuku A et al. IL-27 inhibits hyperglycemia and pancreatic islet inflammation induced by streptozotocin in mice. Am J Pathol 2011; 179: 2327-2336.

34. Cai Y, Yuchi Y, De Groef S, Coppens V, Leuckx G, Baeyens L et al. IL-6-dependent proliferation of alpha cells in mice with partial pancreatic-duct ligation. Diabetologia 2014; 57: 1420-1427.

35. Lin L, Liu A, Peng Z, Lin HJ, Li PK, Li C et al. STAT3 is necessary for proliferation and survival in colon cancer-initiating cells. Cancer Res 2011; 71: 7226-7237.

36. Scholz A, Heinze S, Detjen KM, Peters M, Welzel M, Hauff $P$ et al. Activated signal transducer and activator of transcription 3 (STAT3) supports the malignant phenotype of human pancreatic cancer. Gastroenterology 2003; 125: 891-905.

37. Grivennikov SI, Karin M. Dangerous liaisons: STAT3 and NF-kappaB collaboration and crosstalk in cancer. Cytokine Growth Factor Rev 2010; 21: 11-19.

38. Van de Casteele M, Leuckx G, Baeyens L, Cai Y, Yuchi Y, Coppens V et al. Neurogenin 3+ cells contribute to beta-cell neogenesis and proliferation in injured adult mouse pancreas. Cell Death Dis 2013; 4: e523.

39. Chintinne M, Stange G, Denys B, In 't Veld P, Hellemans K, Pipeleers-Marichal M et al. Contribution of postnatally formed small beta cell aggregates to functional beta cell mass in adult rat pancreas. Diabetologia 2010; 53: 2380-2388.

40. Hirano T, Ishihara K, Hibi M. Roles of STAT3 in mediating the cell growth, differentiation and survival signals relayed through the IL-6 family of cytokine receptors. Oncogene 2000; 19: 2548-2556.
41. Wormald S, Zhang JG, Krebs DL, Mielke LA, Silver J, Alexander WS et al. The comparative roles of suppressor of cytokine signaling- 1 and -3 in the inhibition and desensitization of cytokine signaling. J Biol Chem 2006; 281: 11135-11143.

42. Ortis F, Naamane N, Flamez D, Ladriere L, Moore F, Cunha DA et al. Cytokines interleukin1 beta and tumor necrosis factor-alpha regulate different transcriptional and alternative splicing networks in primary beta-cells. Diabetes 2010; 59: 358-374

43. Latreille M, Herrmanns K, Renwick N, Tuschl T, Malecki MT, McCarthy Ml et al. miR-375 gene dosage in pancreatic beta-cells: implications for regulation of beta-cell mass and biomarker development. J Mol Med 2015; 93: 1159-1169.

44. Erener S, Mojibian M, Fox JK, Denroche HC, Kieffer TJ. Circulating miR-375 as a biomarker of beta-cell death and diabetes in mice. Endocrinology 2013; 154: 603-608.

45. Jakob B, Splinter J, Conrad S, Voss KO, Zink D, Durante M et al. DNA double-strand breaks in heterochromatin elicit fast repair protein recruitment, histone H2AX phosphorylation and relocation to euchromatin. Nucleic Acids Res 2011; 39: 6489-6499.

46. Lu C, Zhu F, Cho YY, Tang F, Zykova T, Ma WY et al. Cell apoptosis: requirement of $\mathrm{H} 2 \mathrm{AX}$ in DNA ladder formation, but not for the activation of caspase-3. Mol Cell 2006; 23 : 121-132.

47. MacPhail SH, Banath JP, Yu Y, Chu E, Olive PL. Cell cycle-dependent expression of phosphorylated histone H2AX: reduced expression in unirradiated but not X-irradiated G1-phase cells. Radiat Res 2003; 159: 759-767.

48. Hernandez L, Terradas M, Martin M, Tusell L, Genesca A. Highly sensitive automated method for DNA damage assessment: gamma-H2AX foci counting and cell cycle sorting. Int J Mol Sci 2013; 14: 15810-15826.

49. Yoshida K, Yoshida SH, Shimoda C, Morita T. Expression and radiation-induced phosphorylation of histone H2AX in mammalian cells. J Radiat Res 2003; 44: 47-51.

50. Miyatsuka T, Kaneto H, Shiraiwa T, Matsuoka TA, Yamamoto K, Kato K et al. Persistent expression of PDX-1 in the pancreas causes acinar-to-ductal metaplasia through Stat3 activation. Genes Dev 2006; 20: 1435-1440.

51. Corcoran RB, Contino G, Deshpande V, Tzatsos A, Conrad C, Benes CH et al. STAT3 plays a critical role in KRAS-induced pancreatic tumorigenesis. Cancer Res 2011; 71: 5020-5029.

52. Tsukiyama S, Matsushita M, Matsumoto S, Morita T, Kobayashi S, Tamura H et al. Transduction of exogenous constitutively activated Stat3 into dispersed islets induces proliferation of rat pancreatic beta-cells. Tissue Eng 2006; 12: 131-140.

53. Lee JY, Ristow M, Lin X, White MF, Magnuson MA, Hennighausen L. RIP-Cre revisited, evidence for impairments of pancreatic beta-cell function. J Biol Chem 2006; 281 2649-2653.

54. Oh HM, Yu CR, Golestaneh N, Amadi-Obi A, Lee YS, Eseonu A et al. STAT3 protein promotes T-cell survival and inhibits interleukin-2 production through up-regulation of Class O Forkhead transcription factors. J Biol Chem 2011; 286: 30888-30897.

55. Tachibana S, Zhang X, Ito K, Ota Y, Cameron AM, Williams GM et al. Interleukin-6 is required for cell cycle arrest and activation of DNA repair enzymes after partial hepatectomy in mice. Cell Biosci 2014; 4 : 6.

56. Thomas HE, Darwiche R, Corbett JA, Kay TW. Interleukin-1 plus gamma-interferon-induced pancreatic beta-cell dysfunction is mediated by beta-cell nitric oxide production. Diabetes 2002; 51: 311-316.

57. Wachlin G, Augstein P, Schroder D, Kuttler B, Kloting I, Heinke P et al. IL-1beta, IFN-gamma and TNF-alpha increase vulnerability of pancreatic beta cells to autoimmune destruction J Autoimmun 2003; 20: 303-312.

58. Oleson BJ, Broniowska KA, Schreiber KH, Tarakanova VL, Corbett JA. Nitric oxide induces ataxia telangiectasia mutated (ATM) protein-dependent gammaH2AX protein formation in pancreatic beta cells. J Biol Chem 2014; 289: 11454-11464.

59. Torbenson M, Yang SQ, Liu HZ, Huang J, Gage W, Diehl AM. STAT-3 overexpression and p21 up-regulation accompany impaired regeneration of fatty livers. Am J Pathol 2002; 161 155-161.

60. Rezende LF, Vieira AS, Negro A, Langone F, Boschero AC. Ciliary neurotrophic factor (CNTF) signals through STAT3-SOCS3 pathway and protects rat pancreatic islets from cytokine-induced apoptosis. Cytokine 2009; 46: 65-71.

61. Hoang PT, Park P, Cobb LJ, Paharkova-Vatchkova V, Hakimi M, Cohen P et al. The neurosurvival factor Humanin inhibits beta-cell apoptosis via signal transducer and activator of transcription 3 activation and delays and ameliorates diabetes in nonobese diabetic mice. Metab Clin Exp 2010; 59: 343-349.

62. Mori H, Shichita T, Yu Q, Yoshida R, Hashimoto M, Okamoto F et al. Suppression of SOCS3 expression in the pancreatic beta-cell leads to resistance to type 1 diabetes. Biochem Biophys Res Commun 2007; 359: 952-958.

63. Laubner K, Kieffer TJ, Lam NT, Niu X, Jakob F, Seufert J. Inhibition of preproinsulin gene expression by leptin induction of suppressor of cytokine signaling 3 in pancreatic beta-cells. Diabetes 2005; 54: 3410-3417.

64. Russell MA, Morgan NG. The impact of anti-inflammatory cytokines on the pancreatic betacell. Islets 2014; 6: e950547.

65. Alvarez-Perez JC, Ernst S, Demirci C, Casinelli GP, Mellado-Gil JM, Rausell-Palamos F et al. Hepatocyte growth factor/c-Met signaling is required for beta-cell regeneration. Diabetes 2014; 63: 216-223.

66. Zong CS, Chan J, Levy DE, Horvath C, Sadowski HB, Wang LH. Mechanism of STAT3 activation by insulin-like growth factor I receptor. J Biol Chem 2000; 275: 15099-15105.

67. Chen H, Gu X, Liu Y, Wang J, Wirt SE, Bottino R et al. PDGF signalling controls agedependent proliferation in pancreatic beta-cells. Nature 2011; 478: 349-355. 
68. De Groef S, Leuckx G, Van Gassen N, Staels W, Cai Y, Yuchi $Y$ et al. Surgical injury to the mouse pancreas through ligation of the pancreatic duct as a model for endocrine and exocrine reprogramming and proliferation. J Vis Exp 2015; 7: e52765.

69. Srinivas S, Watanabe T, Lin CS, William CM, Tanabe Y, Jessell TM et al. Cre reporter strains produced by targeted insertion of EYFP and ECFP into the ROSA26 locus. BMC Dev Bio 2001; $1: 4$.

70. Bogdani M, Lefebvre V, Buelens N, Bock T, Pipeleers-Marichal M, In't Veld P et al. Formation of insulin-positive cells in implants of human pancreatic duct cell preparations from young donors. Diabetologia 2003; 46: 830-838.

71. Abràmoff MD, Magalhães PJ, Ram SJ. Image processing with ImageJ. Biophoton Int 2004; 11: $36-42$.

72. Roels S CO, Brackeva B, Stangé G, De Punt V, Raemdonck C, Ling Z et al. Combinatorial evaluation of miR375 and GAD65 for real-time in vivo pancreatic beta cell destruction. In preparation for Diabetes. (c) (i) Cell Death and Disease is an open-access journal published by Nature Publishing Group. This work is licensed under a Creative Commons Attribution 4.0 International License. The images or other third party material in this article are included in the article's Creative Commons license, unless indicated otherwise in the credit line; if the material is not included under the Creative Commons license, users will need to obtain permission from the license holder to reproduce the material. To view a copy of this license, visit http://creativecommons.org/licenses/by/4.0/

(C) The Author(s) 2016

Supplementary Information accompanies this paper on Cell Death and Disease website (http://www.nature.com/cddis) 